\title{
Antioxidant Properties of Rosemary and Its Potential Uses as Natural Antioxidant in Dairy Products-A Review
}

\author{
Ahmed S. Gad*, Ahmed F. Sayd \\ Dairy Science Department, National Research Centre, Cairo, Egypt \\ Email: asgad2004@yahoo.com \\ Received 2 January 2015; accepted 20 January 2015; published 26 January 2015 \\ Copyright (C) 2015 by authors and Scientific Research Publishing Inc. \\ This work is licensed under the Creative Commons Attribution International License (CC BY). \\ http://creativecommons.org/licenses/by/4.0/

(c) () D Den Access

\section{Abstract}

Dairy products contain lipids rich in polyunsaturated fatty acids and their esters are easily oxidized by molecular oxygen over time. Deleterious changes in dairy products caused by lipid oxidation include not only loss of flavour or development of off-flavours, but also loss of colour, nutrient value, and the accumulation of compounds, which may be detrimental to the health of consumers. One of the most effective ways of retarding lipid oxidation in dairy products is to incorporate antioxidants. Sometimes synthetic phenolic antioxidant, butylated hydroxyanisole (BHA) and butylated hydroxytoluene (BHT) are used to delay this oxidation. Supplementation dairy products with natural antioxidants (polyphenolic compounds) are better using than synthetic antioxidant and could be potentially. The use of rosemary as natural antioxidant in dairy products can reduce the rate of lipid oxidation and hydrolysis besides may be beneficial in increasing the shelf life of these products. This supplementation will move these products into the functional food area under new category as healthy dairy products. This literature review covers the research that has focused on rosemary as antioxidant and anti-inflammatory agent that can inhibit the lipid oxidation and have health benefits by preventing carcinogens from binding to DNA, fight and stop pain. In this review, we survey the previous studies that were conducted on the application of rosemary extract as an antioxidant to extend the shelf life and to minimize nutritional losses of dairy product.

\section{Keywords}

Autoxidation, Rosemary, Natural Antioxidants Agent, Anti-Inflammatory Agent Functional Dairy Products

\footnotetext{
${ }^{*}$ Corresponding author.
}

How to cite this paper: Gad, A.S. and Sayd, A.F. (2015) Antioxidant Properties of Rosemary and Its Potential Uses as Natural Antioxidant in Dairy Products-A Review. Food and Nutrition Sciences, 6, 179-193. 


\section{Introduction}

One of the most common problems occurring in dairy products rich in polyunsaturated fatty acids is lipid oxidation. On the other hand, the hydrolysis of ester bonds in lipids has been shown by many studies to increase lipid oxidation since short chain fatty acids are released in raw milk by hydrolysis and can be responsible for an undesirable rancid flavor [1]. This oxidation may occur during manufacturing, storage, distribution or at final preparation of dairy products. Light, oxygen and transition metals ions are very important factors leading to oxidative changes. Hunziker [2] reported that in metal tanks, the surface of metal ions such as copper and iron may breakdown the unsaturated lipids into oxidation products during storage or transportation of milk resulting in undesirable flavors. Research by Rice [3] and Tanner [4] showed that copper contamination, resulting from contact of the milk with copper in vacuum pans or bottle caps, may cause tallowness in sweetened condensed milk. Off flavors in stored butters, identified as tallowy, oily, and fishy flavors, are considered to be caused by oxidation [5] [6]. Tallowy or oxidized flavor in ice cream has also been greatly researched and has been found to be the result of oxidation of either the phospholipid fraction or the butterfat or both [5] [7].

Objectionable odors and flavors developed in oxidized products are carried out when subcomponents of the products recombine to form compounds such as hydrocarbons, aldehydes, and ketones, which are not found in the fresh product [8]. Many studies showed the formation of aldehyde and ketone compounds during the production and storage milk powder formed during the manufacture and concentration the milk and during the storage [9]. The development of off flavors in dairy products has been a topic of much research from food science perspective over the years. Unsaturated aldehydes can go through oxidation resulting in short chain hydrocarbons forming malonaldehyde.

Low temperature storage favors a slow rate of oxidative change but temperature is only important as a regulator of the rate of oxidative change; as the temperature increases the rate of oxidative change increases too [10] [11]. Oxidation also takes place in the absence of light but at a slower rate. Oxidative deterioration resulted in the formation of peroxides that limited shelf life of dairy products and could be responsible for an undesirable rancid flavor [1] [12] [13].

To increase the shelf life of the food products synthetic antioxidants commonly used in the food industry include butylated hydroxyanisole (BHA) and butylated hydroxytoluene (BHT) to reduce the rate of lipid oxidation and hydrolysis and stabilized free radicals but these antioxidants are not allowed adding to milk (International Dairy Foods Association (IDFA)). Today foods are intended not only to satisfy hunger and to provide necessary nutrients for humans but also to prevent nutrition-related diseases and improve physical and mental well-being of the consumers [14] [15].

The aim of this study is searching to increase the shelf life of dairy products by using natural antioxidants that can delay or inhibit the lipid oxidation or hydrolysis and minimize nutritional losses. Antioxidants, which mainly come derived from plants in the form of phenolic compounds, have increasingly been advocated as "safe and natural" antioxidants exhibit high inhibition activity of the lipid oxidation that is most important to increase the shelf life of dairy products.

The growing interest in the study of natural antioxidant compounds has been accompanied by an increase in the market presence of functional foods or nutraceuticals or health foods. Fortification of dairy products with bioactive components (natural antioxidants compounds) enhances their antioxidant activity and anti-inflammatory properties, which prevent the damaging effects of free radicals [16] and provide various health benefits.

\section{The Addition of Natural Antioxidant to Dairy Products Increases Its Shelf Life}

\subsection{Oxidative Deterioration in Dairy Products}

Lipid oxidation is propagated by the removal of hydrogen atoms and the subsequent addition of oxygen at alpha positions to a fatty acid double bond, producing free radical species R and peroxy radicals (ROO*) as shown in Figure 1.

The peroxy radicals then react with hydrogen from alpha-methylenic groups of other molecules, producing hydroperoxides $(\mathrm{ROOH})$ and new free radicals $\left(\mathrm{R}^{*}\right)$. The hydroperoxides produced, the primary product of lipid oxidation, are unstable compounds and they react in a number of reactions involving substrate degradation and interaction which results in many different compounds of varying flavor thresholds and molecular weights [1]. Hydroperoxides easily decompose involving monomolecular or bimolecular reactions [17]. 


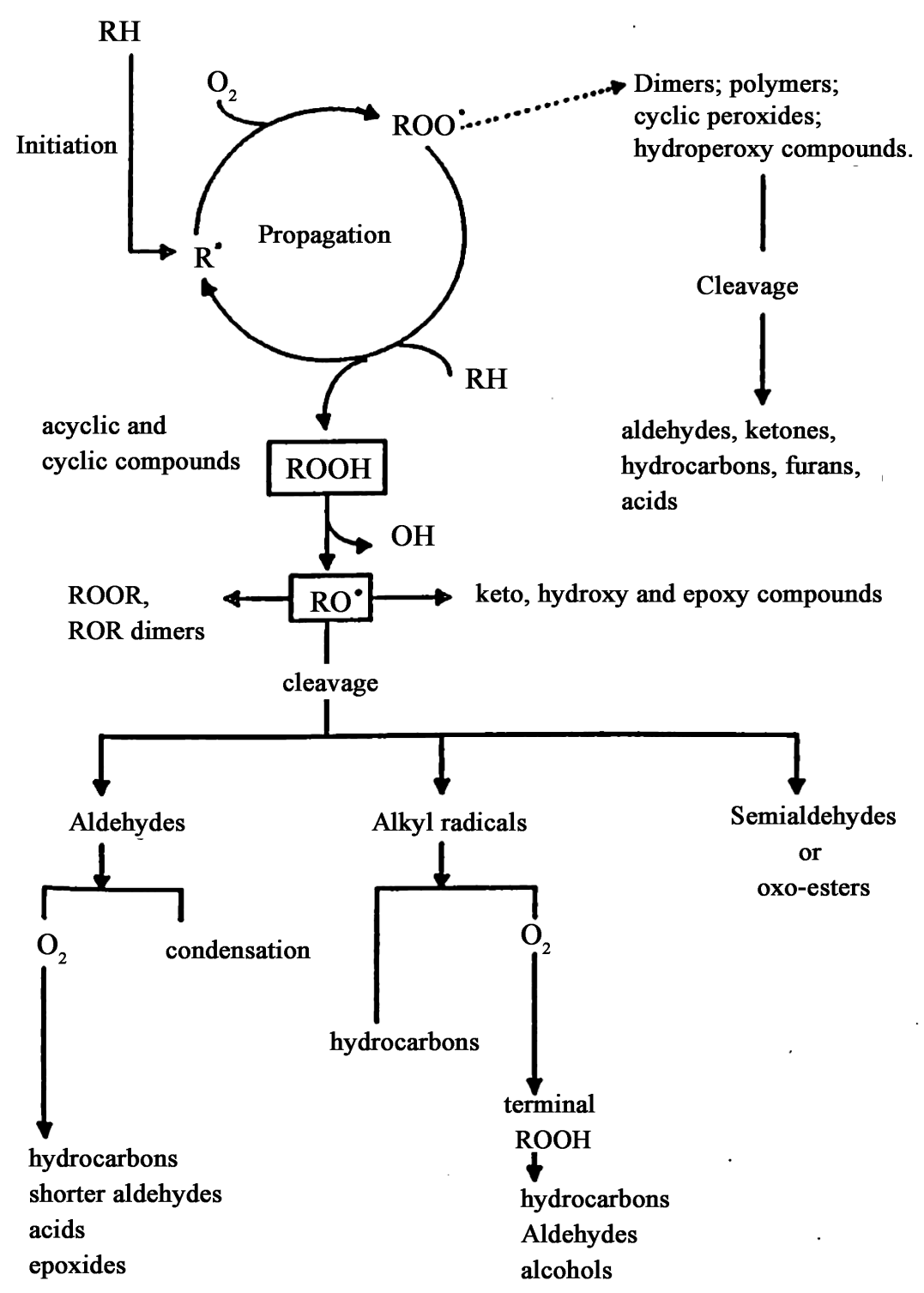

Figure 1. Lipid oxidation schematic (Fennema [1]).

Hydroperoxides is reasonable to determine their concentration as a measure of oxidation. The "peroxide value" test reflects the total concentration of peroxides and hydroperoxides present at a certain time. Hydroperoxides $(\mathrm{LOOH})$ can decompose into alkoxyl (LO) and peroxyl (LOO) highly reactive radicals that may act as initiators of autoxidation. Autoxidation is the oxidative deterioration of unsaturated fatty acids via an auto-catalytic process consisting of a free radical chain mechanism. The mechanism of autoxidation of lipids is a free radical chain reaction which involves the three stages of initiation, propagation and termination. Initiation is the formation of free radicals; propagation is the free radical chain reactions and termination is the formation of nonradical products.

Oxidative deterioration is also a significant contributing factor to the limited shelf life of lipid containing foods and is of great economic concern to the food industry. The oxidation of unsaturated fatty acids resulted in the formation of peroxides, which are susceptible to further decomposition to secondary lipid oxidation byproducts, such as short-chain aldehydes and ketones. Lipid aldehydes are highly reactive and among the most important compounds to contribute to food deterioration, modification of food structure, as well as protein damage via cross linking [18].

Malondialdehyde, a secondary product of lipid oxidation, has received much attention. Since it is a bifunc- 
tional aldehyde, it is a very reactive compound in cross-linking reactions with DNA and proteins [19] [20]. Malonaldehyde formation, a result of the oxidation of unsaturated aldehydes, is the basis for the thiobarbituric acid (TBA) method that is commonly used for measuring fat oxidation [1]. The presence of these molecules, reacting with oxygenated compounds in foods, will adversely affect flavor, taste, nutritional value and overall quality [21]. Tallowy or oxidized flavor in ice cream has also been greatly researched and has been found to be the result of oxidation of either the phospholipid fraction or the butterfat or both [5] [7]. Krukovsky [10] showed that the oxidized flavors in fresh milk, such as chalky and chalky-to-soapy-tallowy, are associated with the deterioration of milk plasma and that metallic and metallic-to-fishy flavors are associated with the deterioration of the fat-globule membrane and oxidation-sensitive fat, respectively.

Lipid oxidation has been long recognized as a major problem in the storage of dairy products containing fat with unsaturated fatty acids. Oxidative changes can result in repugnant flavors, in destruction of valuable nutrients and even in generation of toxic or carcinogenic compounds [22] [23]. Even minute amounts present after processing can translate to greatly accelerate reactions during storage, with parallel changes in flavor, odor, texture, color, and loss of nutritional value [22] [24].

Light and oxygen are very important factors leading to oxidative changes. Another mechanism of oxidation occurs in the presence of sensitizer and UV-light that is photosensitized oxidation. Photo-oxidation pathway is an alternative route leading to the formation of hydroperoxides instead of the free radical mechanism. Excitation of unsaturated fatty acid or oxygen may occur in the presence of light and a sensitizer. There are two types of photo-oxidation [25]. I-an electron or a hydrogen atom transfers between an excited triplet sensitizer and a substrate (PUFA), producing free radicals or radical ions; and II-triplet oxygen $\left({ }^{3} \mathrm{O}_{2}\right)$ can be excited by light to singlet oxygen $\left({ }^{1} \mathrm{O}_{2}\right)$, which reacts with the double bond of unsaturated fatty acids, producing an allylic hydroperoxide [26]. Photosensitized oxidation is a direct reaction of light-activated, singlet oxygen with unsaturated fatty acids, and subsequently hydroperoxides are formed. Photosensitized oxidation happens because of the presence of molecules that can absorb visible or near UV light to become electronically excited (sensitizers).

Transition metal ions $\left(\mathrm{Fe}^{2+}\right.$ and $\mathrm{Fe}^{3+}$ ) can directly braking down unsaturated lipids into lipid oxidation products such as hydroperoxides $(\mathrm{LOOH})$ into alkoxyl ( $\left.\mathrm{LO}^{\circ}\right)$ and peroxyl (LOO') reactive radicals by the following mechanisms: (Schemes 1 and 2).

$$
\begin{aligned}
& \mathrm{Fe}^{2+}+\mathrm{LOOH} \rightarrow \mathrm{Fe}^{3+}+\mathrm{LO}^{\cdot}+\mathrm{OH}^{-} \\
& \mathrm{Fe}^{3+}+\mathrm{LOOH} \rightarrow \mathrm{Fe}^{2+}+\mathrm{LOO}^{\cdot}+\mathrm{H}^{+}
\end{aligned}
$$

(Scheme 1)

(Scheme 2)

The reaction stoichiometry:

In Scheme 1, the moles of $\mathrm{Fe}^{2+}$ oxidized by each mole of hydroperoxide. The reaction mechanism indicates that one lipid hydroperoxide should generate two ferric iron complexes.

In the study by Ueno [27], ultra-high temperature milk was stored under florescent light for 16 hours at $10^{\circ} \mathrm{C}$ and compared to milk stored in the dark for the same time/temperature combination. The results of the study showed that the flavor dilution (FD) chromatograms of nine odorants increased with light exposure, indicating that the off-flavor formation in the light-exposed milk can be attributed to the increase in these nine odorants. The flavor differences between the light-exposed and non-exposed milk were monitored by aroma extract dilution analysis by using aroma extracts prepared from the milk. A panel composed of by 14 trained assessors evaluated the milk samples and rated the intensities of the five odor attributes ("freshness", "fatty”, "metallic", “dusty”, and "overall off-odor”) using a linear scale ranging from 1 (= absent) to 7 (= very strong).

\subsection{Addition of Antioxidant (Phytochemicals-Phenolic Antioxidant) to Milk and Dairy Products Reduce Oxidative Deterioration}

Antioxidants are classified as exogenous (natural or synthetic) or endogenous compounds, both responsible for removal of free radicals, scavenging reactive oxygen species (ROS) or their precursors, inhibiting formation of ROS and binding metal ions needed for catalysis of ROS generation [28].

Natural antioxidant system is sorted in two major groups, enzymatic and non-enzymatic. Enzymatic antioxidants such as catalase, glutathione peroxidase as well as superoxide dismutase (SOD), whereas non-enzymatic antioxidants include direct acting antioxidants against oxidative stress (OS) such as ascorbic and lipoic acid, polyphenols and carotenoids and indirect acting antioxidants include chelating agents and bind to redox metals to prevent free radical generation. 
Antioxidants can be classified according to the mechanism of action to reduce lipid oxidation into two groups:

- First is the primary antioxidant that acts as hydrogen donors to the lipid free radical formed during the lipid oxidation (Figure 2) and rearrange to a stable conformation.

The primary antioxidants $(\mathrm{AH})$ react with lipid peroxyl radicals ( $\left.\mathrm{ROO}^{\circ}\right)$ and convert them to more stable, antioxidant radicals $\left(\mathrm{A}^{*}\right)$. The primary antioxidant is able to scavenge lipid radicals, e.g.:

$$
\mathrm{ROO}^{\circ}+\mathrm{AH} \rightarrow \mathrm{ROOH}+\mathrm{A}^{*}
$$

Antioxidant radicals are stable due to delocalization of the unpaired electron around a phenol ring and cannot easily react with fatty acids. They are able to terminate radical chain process by reacting with radicals, e.g. [29]. These free radical interceptors react with peroxy radicals (ROO*) to stop chain propagation; thus, they inhibit the formation of peroxides.

$$
\mathrm{ROO}^{*}+\mathrm{A}^{*} \rightarrow \mathrm{ROOA}
$$

The most effective antioxidants interrupt the free radical chain reaction and usually contain aromatic rings capable of donating $\mathrm{H}^{*}$ to the free radical formed during lipid oxidation. The formed antioxidant radical is stabilized by delocalization of the unpaired electron around the phenol ring to form a stable resonance hybrid (Figure 3).

- Second is the secondary antioxidant, in opposite to the primary antioxidants, do not break free radical chain or do not convert free radicals into stable molecules. Secondary antioxidant act through various mechanisms to slow the rate of oxidation reactions, as: reducers and chelators of metal ions, provide $\mathrm{H}$ to primary antioxidants, decompose hydroperoxide to nonradical species, deactivate singlet oxygen, absorb ultraviolet radiation, or act as oxygen scavengers [29].

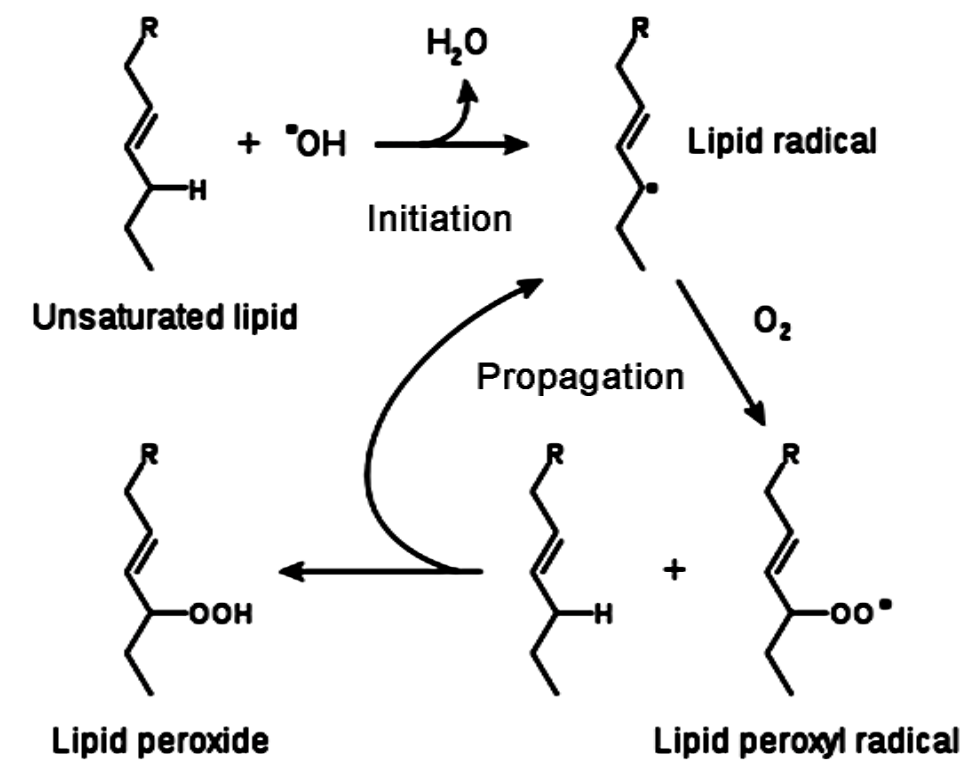

Figure 2. Unsaturated lipid oxidation formed lipid free radical.
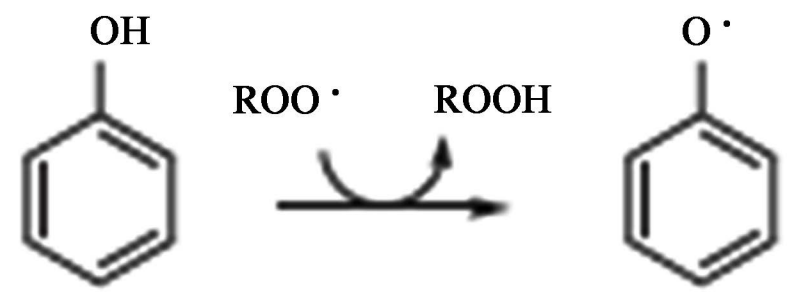

Figure 3. The formed antioxidant radical is stabilized by delocalization of the unpaired electron around the phenol ring to form a stable resonance hybrid. 
Phenolic compounds are bioactive substances widely distributed in plants act as radical scavengers [30] or metal chelators [31] and stabilize of lipid oxidation [32]-[35]. Therefore, these compounds have been considered as promising candidates as potential protectors against lipid oxidation. The presence of an antioxidant is one of the fastest ways to reduce fat oxidation [36].

Several types of natural plant derived antioxidants have been studied, including extracts of grape seed, sage, thyme, rice bran, white peony, red peony, sappanwood, moutan peony, rehmania or angelica, sedge, marjoram, wild marjoram, caraway, basil extract, ginger, plum concentrates, aloe vera, mustard, tea catechins, and rosemary extract [37]-[41]. Much of the research devoted to natural plant derived antioxidants focuses on rosemary extract [42]-[50]. Plant extracts containing high levels of phenolic compound with strong $\mathrm{H}^{\bullet-}$ donating activity effectively scavenge $\mathrm{H}_{2} \mathrm{O}_{2}$ and reactive oxygen species [51].

\subsection{Rosemary (the Bioactive Component as Natural Antioxidant)}

Rosemary (Rosemarinus offcinalis L.) has always been known a versatile, aromatic herb and addition to being used as a food flavoring is also known medicinally for its powerful antioxidant activity, antibacterial and antimutagenic properties [52].

Rosemary (Rosmarinus officinalis L.) leaves, widely used food ingredient for flavoring and has been known as a traditional medicinal plant for its health beneficial properties such as antimicrobial, antialgesic, and antirheumatic effects. Its antioxidant [53] [54], anti-inflammatory [55], and anti-cancer [56] activities are reported by previous research groups.

Rosemary extract contained the highest concentration of phenolic substances obtained from the leaves of the evergreen shrub rosemary [57]. The phenolic compounds responsible for rosemary antioxidant activity are mainly phenolic diterpenes such as carnosol, carnosic acid, rosmanol, epirosmanol and isorosmanol as shown in Figure 4 [58] [60]. Rosmanol is a potent antioxidant having inhibition effect of superoxide anion production, as well as lipid peroxidation and free radical scavenging activities [61]-[63].

The polyphenol, rosmarinic acid has 2 aromatic rings, each with 2 -OH groups that are capable of donating $\mathrm{H}$. and chelating metals. Hra [64] reported that rosemary extract exhibited antioxidant activity superior to $\alpha$-tocopherol. Rosemary oleoresin has been reported to contain several components such as rosmanol, rosmariquinone, rosmaridiphenol, and carnosol that may be up to four times as effective as BHA and equal to BHT as an antioxidant [65]-[67]. Extensive studies [68] [69] on rosemary extracts containing carnosol, carnosic acid, and rosmarinic acid have shown that the activities of these natural antioxidants are system-dependent and that their

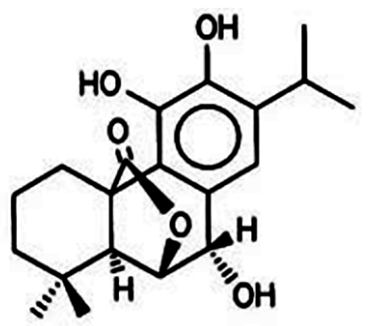

rosmanol

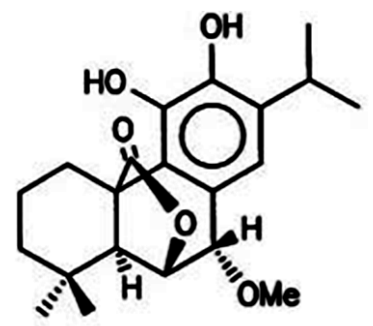

7-methyl-epirosmanol

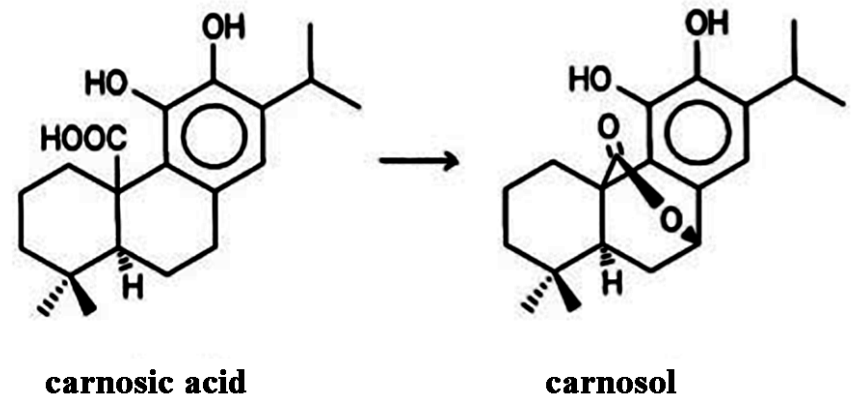

Figure 4. Structures of some antioxidants in rosemary extracts. 
effectiveness in different food systems is difficult to predict.

\subsection{The Addition of Rosemary Extract to Dairy Products Inhibit the Lipid Oxidation}

Milk powder and similar concentrated milk products, such as condensed milk, ice cream preparations, coffee creamers and whole milk-based confectionary fillings, are highly sensitive to oxidation and have very limited shelf life due to high-fat content and nutritional composition.

The addition of this natural antioxidant (rosemary extract) could prove useful in preventing lipid oxidation and the development of off flavors and aromas. These hydrophilic antioxidants are oriented in the oil-air interface and protect the bulk oil phase from oxidation. Phenolic compounds obtained from rosemary are shown to act as antioxidant that reduces the extent of oxidation of dietary lipids [70]. Rosemary exhibited the highest ability to inhibit lipid peroxidation [71]. The antioxidant action of rosemary is shown to be dependent on the ability of their constituent phenolic compounds to scavenge (trap) free radicals and to chelate metals [72] [73].

There are limited researches done on the addition of rosemary extract to dairy products. Formulating dairy products with rosemary requires knowledge of their interaction and way they're affected by the processing treatment used. Knowing when, and how, to incorporate rosemary extract into a mix also is vital to preserving its functional characteristics.

Gad and Abd El-Salam [74] monitored the effect of addition different concentration of rosemary extract to skim milk on through processing of production soft cheese. Results show that rennet coagulation time (RCT) of skim milk/rosemary extract increased. The RCT of skim milk/rosemary extracts also increased with increasing the ratio of the added extracts to skim milk. The antioxidant activity of the skim milk/rosemary extracts blends was improved by heat treatment and the addition of calcium chloride and pasteurization significantly increased markedly the phenol content and the antioxidant activity of skim milk. Whereas addition of sodium chloride and homogenization to the skim milk/rosemary extracts does not affect on antioxidant activity. Skim milk with high rosemary concentration has high antioxidant activity.

In manufacture UF-soft cheese [75] supplemented UF milk retentate (1.5\% fat) with $1 \%$ - $5 \%$ rosemary extract (RE) and cold storage for 30 days. The total phenolic content (TPC) and antioxidant capacity using DPPH and FRAP methods was evaluated in produced cheese. Results show total phenolic content (TPC) and antioxidant capacity in cheese made from milk retentate/rosemary extracts increase and consequently, its antioxidant activity whereas these values are less after 30 days storage.

Production functional yoghurt supplemented with rosemary extract as natural antioxidant $\mathrm{s}$ is studied. Apparent viscosity was measured as physical quality parameter and antioxidant values are evaluated estimated by 2,2-diphenyl-1-picrylhydrazyl (DPPH) scavenging, ferric reducing antioxidant power (FRAP) reducing activities and phenolic compound content when fresh and during storage at $5^{\circ} \mathrm{C} \pm 2{ }^{\circ} \mathrm{C}$ for 12 days. The modeling results show that soluble phenolic content in yogurt is increased with increasing the concentration of rosemary extract mixed with skim milk and is strongly correlated with antioxidant activity and decreased over the same time period. Apparent viscosity does not affect as concentration supplemented [76].

Product such as dry cheese powder contain lipid (polyunsaturated fat and their esters) are very susceptible to oxidation to oxidation over time. Such oxidation could be inhibited by use of rosemary oleoresin and thus possibly extending the shelf life of such products. The percentage of rosemary oleoresin as a natural antioxidant added directly would be crucial in effectively retarding lipid oxidation of the cheese powder [77] [78].

Commercial ricotta cheese and $15 \%$ of milk cream (25.0\% fat) were the basis of the formulation, in which were added the concentrated extracts of rosemary. The formulations containing extracts was evaluated for sensory properties through an acceptance test and ideal scale, using 50 tasters a 9-point hedonic scale was used. Physical and chemical characterization was assessed. Results show that ricotta cheese containing rosemary extract had $76.0 \%$ of acceptance, with $96 \mathrm{mg} / 100 \mathrm{~g}$ phenolic compounds in the final product, corresponding to $9.6 \%$ of the Recommended Daily Intake.

Kilcawley [79] reported that the extent of lipolysis in Cheddar cheeses has a major impact on its sensory characteristics and cheeses aged longer were associated with rancidity. Since excessive lipolysis in Cheddar cheese is widely associated with downgrading due to oxidative rancidity, this study shows a potential use of rosemary oleoresin showed a potential effect as an antioxidant to inhibit oxidation in aged cheese [80]. Consequently, the use of rosemary extract as a natural antioxidant could increase the shelf life of Cheddar cheese or cheese powder by inhibiting oxidation. 
The use of rosemary extract as a natural antioxidant could increase the shelf life of dairy products by inhibiting oxidation. A more thorough understanding of the mechanisms of lipid auto-oxidation in milk may lead to a better understanding of how added natural antioxidants, such as rosemary oleoresin, can help inhibit such oxidation and sensory changes in milk and dairy products. Rosemary antioxidants are in most applications more effective than vitamin E (synthetic), BHA, BHT, TBHQ and others. A new application for rosemary-derived antioxidant, extend the shelf life of milk powder and other dairy products. Development of functional dairy products will continue to grow through the $21^{\text {st }}$ century as consumer demand for healthful products.

\section{Health Benefits of Rosemary}

Rosemary has antioxidant and anti inflammatory activity in biological systems. Functional dairy products supplemented with rosemary could play a role in reducing the risk of some common diseases since its contents of antioxidant components can prevent chemical damage to the cells' components by oxidation and can interfere with the oxidation process by reacting with the free radicals, chelating free catalytic metals and also by acting as free radical scavengers [81].

\subsection{Rosemary as Antioxidant Agent May Reduce the Risk of Illnesses}

In biological system, many oxidation reactions are absolutely essential for our survival. Sometimes, inside the normal cells, oxidation reactions release uncontrolled reactions and produce unstable oxygen molecules "free radicals". These produced compounds will react with many different important molecules in vital organs like lipid, protein and DNA forming new compound that damage DNA. Increased oxidative stress (OS), resulting from an imbalance between oxidant attack due to free radical production and antioxidant defense.

Antioxidants are the first line of defense against free radical damage (Figure 5) and are critical for maintaining optimum health and wellbeing. It is important human daily intake enough antioxidant supplementation in combination state, that increased level of antioxidant in serum. Food is used as a delivery for antioxidant to human body to improve human health. Introduce antioxidants into dairy products to demonstrate their benefits to human health.

Research has shown that natural antioxidants could play a vital role in fighting diseases caused by oxidative damage and even decrease the formation and mutagenicity of heterocyclic amines (HCAs) in cooked meat [50] [82].

\subsection{Rosemary as Anti-Inflammatory May Reduce the Incidence of Various Diseases}

Inflammation is a normal protective response induced by tissue injury or infection and functions to combat invaders in the body (microorganisms and non-self cells) and to remove dead or damaged host cells [83]. The term inflammation is derived from the Latin word-Inflammare, means burn. According to the modern concept,

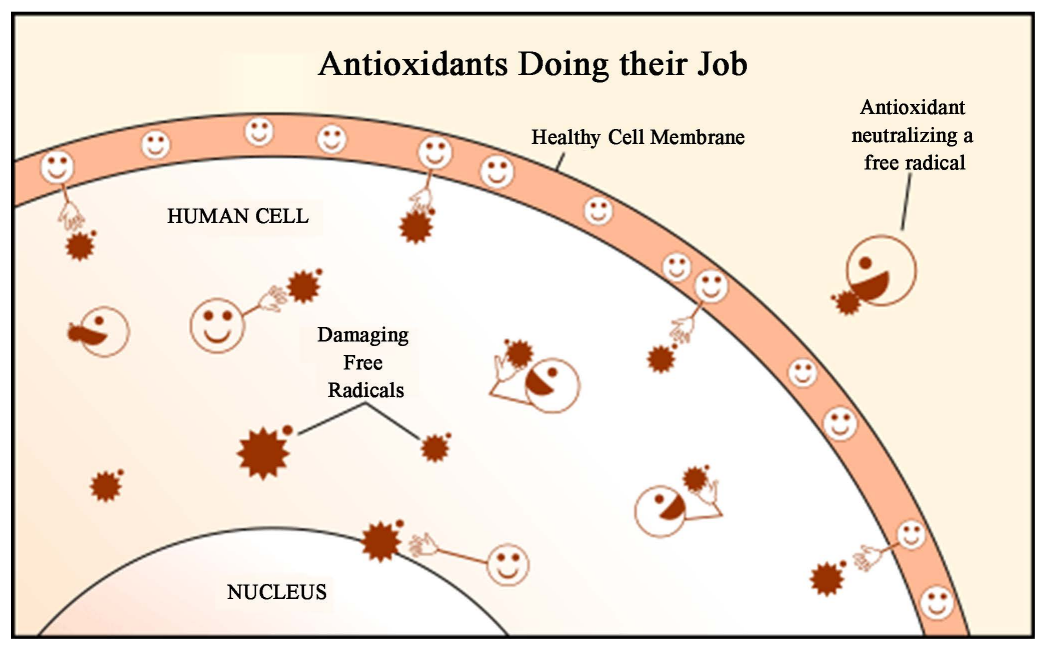

Figure 5. Natural antioxidants neutralizing free radicals. 
inflammation is a healthy process resulting from some disturbance or disease. Inflammation can be classified two categories: acute inflammation and chronic inflammation. Acute inflammation is the initial response of the immune system against pathogens, injured tissue, and small particles and a rapid self-limiting process. This acute inflammation is a short-term response of our body, usually appearing within a few minute or hours after exposure to the injurious stimulus and stopped when this stimulus is eliminated (Figure 6).

The acute inflammation is initiated by resident immune cells which are already present in all tissues. The immune cells such as macrophages, dendritic cells, and mast cells are activated by an infection, burning, or other injuries and release inflammatory mediators which can cause the clinical signs of inflammation. The acute inflammation causes an increase in the vascular permeability, releasing compounds related to the inflammatory response. During the acute inflammation, if phagocytes fails to eliminate pathogen, or immune system cannot repair injured tissue, the inflammation can be developed to chronic inflammation.

In chronic inflammation, various cytokines and growth factors are released, resulting recruitment of higher order immune cells such as leukocytes, lymphocytes and fibroblasts. The inflammation can lead to persistent tissue damages by these cells. In addition, many research groups report evidence that chronic inflammation lies at the basis of many diseases of advanced age such as heart attacks, Alzheimer's diseases, and cancer [84] [85].

To preserve healthy body, two sets of mechanisms must be matched: the ability to increase a rapid inflammatory response to injurious pathogens and the ability to keep this response from prolonged. Anti-inflammatory substances can be an effective tool in the therapeutic treatment of the diseases. There are many chemical reagents have anti-inflammatory activities may reduce the incidence of various disease derived from inflammation by blocking (inhibited or suppressed) activities (inflammatory process). Most of the anti-inflammatory drugs

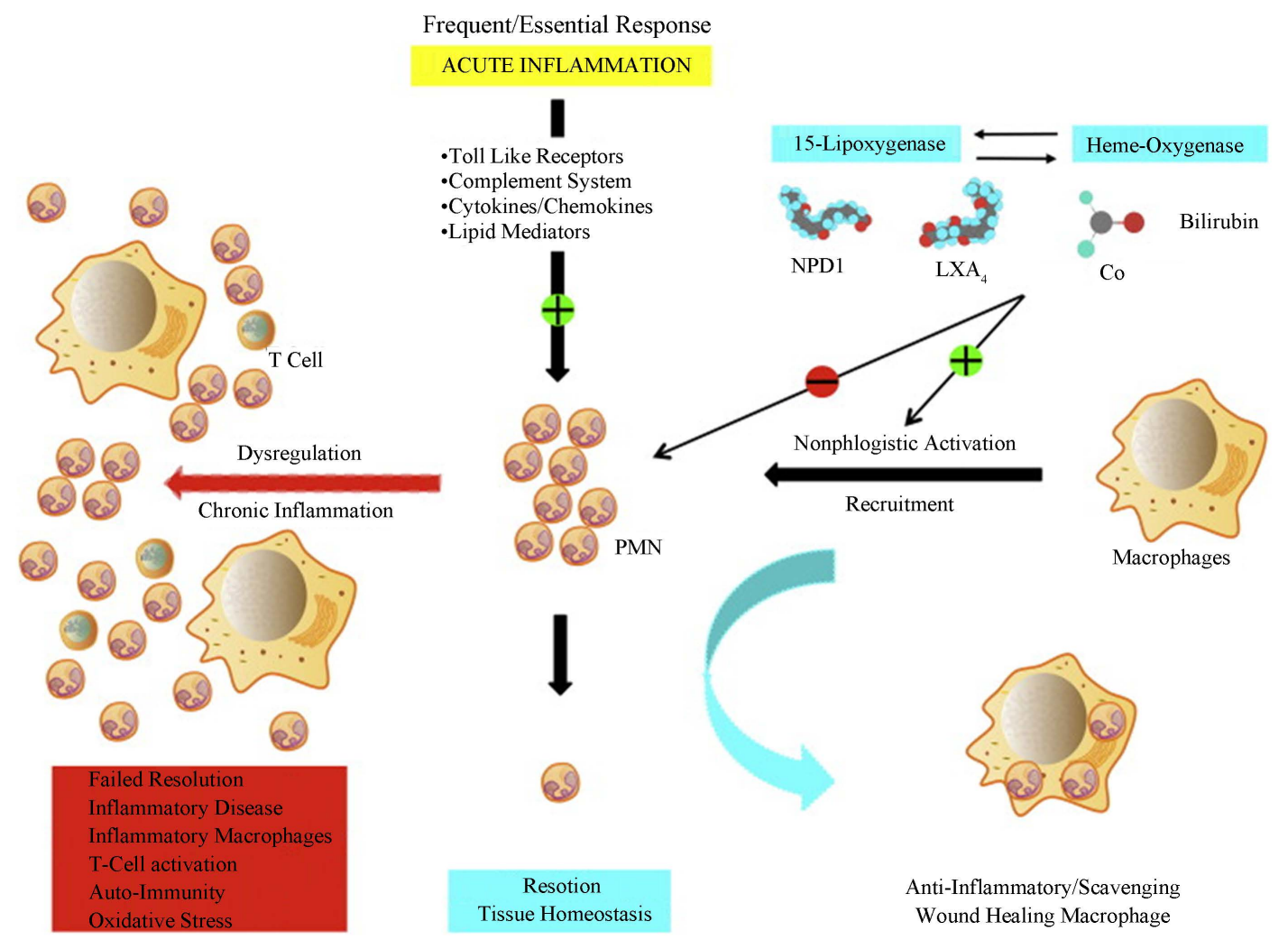

Figure 6. Beneficial inflammation requires active resolution. Tissues experience frequent acute inflammation in response to injury, stress or infection. Recruitment of vascular PMN is initiated and amplified by carefully regulated pro-inflammatory circuits. Successful execution of acute inflammation requires phagocytosis of spent PMN by macrophages, a non-inflammatory response. Phagocytosis of PMN induces formation of anti-inflammatory mediators and differentiation to wound healing macrophages, which are essential to restore normal tissue function. Resident circuits in the cornea, uvea and retina, namely 15-LOX and/or HO produce autacoids that counter-regulate pro-inflammatory circuits, reduce PMN infiltration and activate macrophages to remove PMN. Dysregulation of this fundamental process leads to failed PMN resolution, activation of inflammatory macrophages and T-cells, setting the stage for an inflammatory disease. 

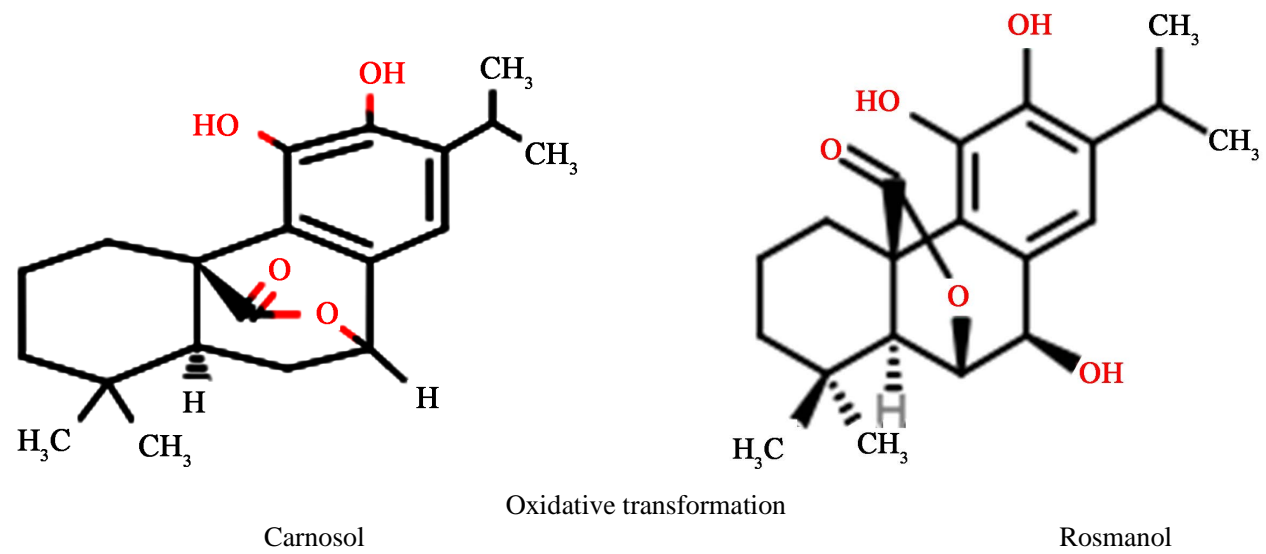

Figure 7. Chemical structure of carnosol and rosmanol.

now available are potential inhibitors of cyclooxygenase (COX) pathway of arachidonic acid metabolism which produces prostaglandins. Gastrointestinal problems associated with the use of anti-inflammatory drugs are still an enduring dilemma of medical world. It is very important that profound research with ethnobotanical plants possessing anti-inflammatory and analgesic properties can definitely open up new vistas in inflammatory disorders.

Purified natural compounds from plants (such medicinal plants with anti-inflammatory) can serve as template for the synthesis of new generation anti-inflammatory drugs with low toxicity and higher therapeutic value. Medicinal plants and their isolated compounds are employed worldwide in folk medicine to treat different inflammatory conditions. Rosemary (Rosmarinus officinalis L.) belongs to the family Labiatae (Lamiaceae) and has been an important medicinal plant since earliest times. Rosemary is antiflammatory herb that can fight and climinate (stop) pain. Incorporation antiflammatory food in our diet lower inflammation our body.

Many studies have revealed that antioxidant activity of rosemary extract is mainly due to the presence of, rosmarinic acid (RA) and carnosic acid (CA), which are both responsible for the anti inflammatory and antioxidant properties [86] [87]. Carnosol converted into rosmanol via oxidation in food processing (Figure 7).

Carnosol has known as an anti-inflammatory compound in rosemary extract. Rosmanol is transformed from carnosol. Carnosic acid and carnosol are powerful compounds in rosemary extracts. These compounds have anti-inflammatory and anti-cancer activities. Anti-inflammatory agent and that it prevent carcinogens from binding to DNA, and stimulates liver detoxification of carcinogens. Study has demonstrated that rosmarinic acid of a rosemary extract inhibited the allergic airway inflammation induced by house dust mites in vivo and another study of perilla has shown that the volatile constituents also prevented allergic airway inflammation induced by house dust mites. The preventive effect is associated with inhibition of the enhanced local expression of interleukin-13 [88].

\section{Conclusion}

Lipid oxidation is a major degradative reaction limiting shelf life and destroying quality of foods. The average consumer recognizes lipid oxidation as "rancidity". This review shows that dairy products which have containing fat with unsaturated fatty acids are usually affected (as lipid oxidized) by air, light, contamination by metals, $\mathrm{pH}$, salt content and storage temperature and finally give off flavors with limited shelf life of the products. To delay lipid oxidation and extend the shelf life of dairy products, antioxidant must be added. Synthetic antioxidants are commonly used in the food industry to delay or inhibit the lipid oxidation whereas it is not allowed to be used in dairy products. Natural antioxidants are safe and can help to inhibit such oxidation. Polyphenolic compounds consider significant contributing factor to the limited shelf life as well as possibly health-protecting compounds. Rosemary extract may be up to four times as effective as BHA and equal to BHT as a phenolic antioxidant. This natural antioxidant has a limited research done on the shelf life and subsequent sensory analysis of dairy products. Besides natural antioxidants used to reduce the rate of lipid oxidation and increased the shelf life of the products, these products are improving their antioxidant potential giving functional dairy products and give maximal health benefit. Rosemary is a powerful antioxidant and anti-inflammatory agent, and it is believed 
to have benefits on various diseases and conditions. It is obviously that there has a limited research done on the addition of rosemary extract to dairy products and needs more investigations.

\section{References}

[1] Fennema, O.R. (1999) Food Chemistry. 3rd Edition, Marcel Dekker, New York, 1067.

[2] Hunziker, O.F., Cordes, W.A. and Nissen, B.H. (1929) Metals in Dairy Equipment. Metallic Corrosion in Milk Products and Its Effect on Flavor. Journal of Dairy Science, 12, 140-148.

http://dx.doi.org/10.3168/jds.S0022-0302(29)93566-9

[3] Rice, F.E. (1926) Sweetened Condensed Milk: VI. Tallowiness. Journal of Dairy Science, 9, 459-468. http://dx.doi.org/10.3168/jds.S0022-0302(26)93914-3

[4] Tanner, M.S., Bhave, S.A., Kantarjian, A.H. and Pandit, A.N. (1983) Early Introduction of Copper-Contaminated Animal Milk Feeds as a Possible Cause of Indian Childhood Cirrhosis. The Lancet, 322, 992-995. http://dx.doi.org/10.1016/S0140-6736(83)90980-7

[5] Brown, W.C. and Thurston, L.M. (1940) A Review of Oxidation in Milk Products as Related to Flavor. Journal of Dairy Science, 23, 629-685. http://dx.doi.org/10.3168/jds.S0022-0302(40)95555-2

[6] Krause, A.J., Miracle, R.E., Sanders, T.H., Dean, L.L. and Drake, M.A. (2008) The Effect of Refrigerated and Frozen Storage on Butter Flavor and Texture. Journal of Dairy Science, 91, 455-465. http://dx.doi.org/10.3168/jds.2007-0717

[7] Shiota, M., Takahashi, N., Konishi, H. and Yoshioka, T. (2012) Impact of Oxidized Off-Flavor of Ice Cream Prepared from Milk Fat. Journal of Oil and Fat Industries, 81, 455-460.

[8] Lee, K.G. and Shibamoto, T. (2002) Determination of Antioxidant Potential of Volative Extracts Isolated from Various Herbs and Spices. Journal of Agricultural and Food Chemistry, 50, 4947-4952. http://dx.doi.org/10.1021/jf0255681

[9] Li, Y.H., Zhang, L.W. and Wang, W.J. (2012) Formation of Aldehyde and Ketone Compounds during Production and Storage Milk Powder. Molecule, 17, 9900-9911. http://dx.doi.org/10.3390/molecules17089900

[10] Krukovsky, V.N. (1951) The Origin of Oxidized Flavors and Factors Responsible for Their Development in Milk and Milk Products. Cornell University, Ithaca.

[11] Lloyd, M.A., Zou, J., Ogden, L.V. and Pike, O.A. (2004) Sensory and Nutritional Quality of Nonfat Dry Milk in LongTerm Residential Storage. Journal of Food Science, 69, 326-331. http://dx.doi.org/10.1111/j.1750-3841.2004.tb18025.x

[12] Corbett, W.J. and Tracy, P.H. (1941) Experiments on the Use of Certain Antioxidants for Control of Oxidized Flavor in Dairy Products. Food Research, 6, 445-459. http://dx.doi.org/10.1111/j.1365-2621.1941.tb16303.x

[13] Jeon, I.J. (1996) Undesirable Flavors in Dairy Products. In: Food Taints and Off-Flavours, Blackie Academic and Professional, New York, 139-167. http://dx.doi.org/10.1007/978-1-4615-2151-8_5

[14] Menrad, K. (2003) Market and Marketing of Functional Food in Europe. Journal of Food Engineering, 56, 181-188. http://dx.doi.org/10.1016/S0260-8774(02)00247-9

[15] Roberfroid, M.B. (2000) A European Consensus of Scientific Concepts of Functional Foods. Nutrition, 16, 689-691. http://dx.doi.org/10.1016/S0899-9007(00)00329-4

[16] Berardini, N., Knodler, M., Schieber, A. and Carle, R. (2005) Utilization of Mango Peels as a Source of Pectin and Polyphenolics. Innovations in Food Science and Emerging Technologies, 6, 442-452. http://dx.doi.org/10.1016/j.ifset.2005.06.004

[17] Belitz, H.D. and Grosch, W. (1999) Food Chemistry. Springer-Verlag, Berlin, 184-189. http://dx.doi.org/10.1007/978-3-662-07281-3

[18] Schaich, K.M. (2008) Chapter 8: Co-Oxidations of Oxidizing Lipids: Reactions with Proteins. In: Kamal-Eldin, A. and Min, D., Eds., Lipid Oxidation Pathways, 183-274.

[19] Addis, P.B. (1986) Occurrence of Lipid Oxidation Products in Foods. Food and Chemical Toxicology, 24, 1021-1030. http://dx.doi.org/10.1016/0278-6915(86)90283-8

[20] Kubow, S. (1990) Toxicity of Dietary Lipid Peroxidation Products. Trends Food Science and Technology, 1, 67-71. http://dx.doi.org/10.1016/0924-2244(90)90049-5

[21] Vercellotti, J.R., Angelo, A.J.S. and Spanier, A.M. (1992) Lipid Oxidation in Foods, an Overview. In: St Angelo, A.J. Ed., Lipid Oxidation in Food, American Chemical Society, Washington DC, 1-14.

[22] Schaich, K.M. (2012) Lipid Oxidation. In: Eskin, N.A.M., Ed., Biochemistry of Foods, 3rd Edition. Elsevier, New York.

[23] Shahidi, F. (1998) Indicators for Evaluation of Lipid Oxidation and Off-Flavor Development in Food. In: Food Flavors: Formation, Analysis and Packaging Influences, 55-68. 
[24] Schaich, K.M. (2009) Lipid Oxidation: A Chemical Stabilization Challenge for Packaging. In: Yam, K.L. Ed., The Wiley Encyclopedia of Packaging Technology, 3rd Edition, John Wiley and Sons Inc., New York, 659-674.

[25] Gordon, M.H. (2001) The Development of Oxidative Rancidity. In: Pokorny, J., Yanishlieva, N. and Gordon, M., Eds., Antioxidants in Food-Practical Applications, CRC Press, Washington DC, 7-21. http://dx.doi.org/10.1016/9781855736160.1.5

[26] Frankel, E.N. (1995) Chemistry of Autoxidation: Mechanism, Products and Flavor Significance. In: Min, D.B and Smouse, T.H., Eds., Flavor Chemistry of Fats and Oils, AOCS, Urbana-Champaign, 1-38.

[27] Ueno, T., Suzuki, Y., Ho, C. and Masuda, H. (2007) Formation of Off-Odorants during Light Exposure of Milk and Its Inhibition by Antioxidants. ACS Symposium Series, 956, 390-400.

[28] Gilgun-Sherki, Y., Melamed, E. and Offen, D. (2001) Oxidative Stress Induced-Neurodegenerative Diseases: The Need for Antioxidants That Penetrate the Blood Brain Barrier. Neuropharmacology, 40, 959-975. http://dx.doi.org/10.1016/S0028-3908(01)00019-3

[29] Reische, D.W., Lillard, D.A. and Eitenmiller, R.R. (2002) Antioxidants. In: Akoh, C.C. and Min, D.B., Eds., Food Lipids: Chemistry, Nutrition and Biotechnology, Marcel Dekker, New York, 489-516. http://dx.doi.org/10.1201/9780203908815.ch15

[30] Antolovich, M., Prenzler, P.D., Patsalides, E., McDonald, S. and Robards, K. (2002) Methods for Testing Antioxidant Activity. The Analyst, 127, 183-198. http://dx.doi.org/10.1039/b009171p

[31] Liao, K. and Yin, M. (2000) Individual and Combined Antioxidant Effects of Seven Phenolic Agents in Human Erythrocyte Membrane Ghosts and Phosphatidylcholine Liposome Systems: Importance of the Partition Coefficient. Journal of Agricultural and Food Chemistry, 48, 2266-2270. http://dx.doi.org/10.1021/jf990946w

[32] Abdalla, A.E. and Roozen, J.P (2001) The Effects of Stabilized Extracts of Sage and Oregano on the Oxidation of Salad Dressings. European Food Research and Technology, 212, 551-556. http://dx.doi.org/10.1007/s002170100288

[33] Astley, S.B. (2003) Dietary Antioxidants-Past, Present and Future. Trends in Food Science and Technology, 14, 9398. http://dx.doi.org/10.1016/S0924-2244(02)00281-9

[34] Loliger, J., Lambelet, P., Aeschbach, R. and Prior, E.M. (1996) Natural Antioxidants: From Radical Mechanisms to Food Stabilization. In: McDonald, R.E. and Min, D.B., Eds., Food Lipids and Health, Marcel Dekker Inc., New York, 315-344.

[35] Shahidi, F. and Wanasundara, P.K.J. (1992) Phenolic Antioxidants. Critical Reviews in Food Science and Nutrition, 32, 67-103. http://dx.doi.org/10.1080/10408399209527581

[36] Karpinska, M., Borowski, J. and Danowska, O.M. (2001) The Use of Natural Antioxidants in Ready-to-Serve Food. Food Chemistry, 72, 5-9. http://dx.doi.org/10.1016/S0308-8146(00)00171-0

[37] El-Alim, S.L.A., Lugasi, A., Hóvári, J. and Dworschák, E. (1999) Culinary Herbs Inhibit Lipid Oxidation in Raw and Cooked Minced Meat Patties during Storage. Journal of the Science of Food and Agriculture, 79, 277-285. http://dx.doi.org/10.1002/(SICI)1097-0010(199902)79:2<277::AID-JSFA181>3.0.CO;2-S

[38] Fiorentino, A., Ricci, A., D’Abrosca, B., Pacifico, S., Golino, A., Letizia, M., Piccolella, S. and Monaco, P. (2008) Potential Food Additives from Carex distachya Roots: Identification and in Vitro Antioxidant Properties. Journal of Agricultural and Food Chemistry, 56, 8218-8225. http://dx.doi.org/10.1021/jf801603s

[39] Han, J. and Rhee, K.S. (2004) Antioxidant Properties of Selected Oriental Non-Culinary/Nutraceutical Herb Extracts as Evaluated in Raw and Cooked Meat. Meat Science, 70, 25-33. http://dx.doi.org/10.1016/j.meatsci.2004.11.017

[40] Namiki, M. (1990) Antioxidant Antimutagens in Food. Critical Reviews in Food Science and Nutrition, 29, $273-300$. http://dx.doi.org/10.1080/10408399009527528

[41] Nuñez de Gonzalez, M.T., Hafley, B.S., Boleman, R.M., Miller, R.K., Rhee, K.S. and Keeton, J.T. (2008) Antioxidant Properties of Plum Concentrates and Powder in Precooked Roast Beef to Reduce Lipid Oxidation. Meat Science, 80, 997-1004. http://dx.doi.org/10.1016/j.meatsci.2008.04.014

[42] Armitage, D.B., Hettiarachchy, N.S. and Monsoor, M.A. (2002) Natural Antioxidants as a Component of an Egg Albumen Film in the Reduction of Lipid Oxidation in Cooked and Uncooked Poultry. Journal of Food Science, 67, 631634.

[43] Barbut, S., Josephson, D.B. and Maurer, A.J. (1985) Antioxidant Properties of Rosemary Oleoresin in Turkey Sausage. Journal of Food Science, 50, 1356-1359. http://dx.doi.org/10.1111/j.1365-2621.1985.tb10476.x

[44] Barbut, S., Draper, H.H. and Hadley, M. (1988) Effects of Freezing Method on Lipid Oxidation in Turkey Sausage. Journal of Food Protection, 51, 878-882.

[45] Botsoglou, N.A., Govaris, A., Giannenas, I., Botsoglou, E. and Papageorgiou, G. (2007) The Incorporation of Dehydrated Rosemary Leaves in the Rations of Turkeys and Their Impact on the Oxidative Stability of the Produced Raw and Cooked Meat. International Journal of Food Sciences and Nutrition, 58, 312-320. 
http://dx.doi.org/10.1080/09637480701228583

[46] Duxbury, D.D. (1989) Decolorized, Deflavorized Rosemary Extracts Antioxidant Properties Retard Oxidative Rancidity. Food Processing, 50, 62-67.

[47] Jaswir, I. and Man, Y.B.C. (1999) Use Optimization of Natural Antioxidants in Refined Bleached and Deodorized palm Olein during Repeated Deep-Fat Frying Using Response Surface Methodology. Journal of the American Oil Chemists' Society, 76, 341-348.

[48] Murphy, A., Kerry, J.P., Buckley, J. and Gray, I. (1998) The Antioxidative Properties of Rosemary Oleoresin and Inhibition of Off-Flavours Precooked Roast Beef Slices. Journal of the Science of Food Agriculture, 77, 235-243. http://dx.doi.org/10.1002/(SICI)1097-0010(199806)77:2<235::AID-JSFA30>3.0.CO;2-L

[49] Sanchez-Escalante, A., Djenane, D., Torrescano, G., Beltran, J.A. and Roncales, P. (2003) Antioxidant Action of Borage, Rosemary, Oregano, and Ascorbic Acid in Beef Patties Packaged in Modified Atmosphere. Journal of Food Science, 68, 339-344. http://dx.doi.org/10.1111/j.1365-2621.2003.tb14162.x

[50] Tsen, S.Y., Ameri, F. and Smith, J.S. (2006) Effects of Rosemary Extracts on the Reduction of Heterocyclic Amines in Beef Patties. Journal of Food Science, 71, 469-473. http://dx.doi.org/10.1111/j.1750-3841.2006.00149.x

[51] Lugasi, A., Dworschak, E. and Hovari, J. (1995) Characterization of Scavenging Activity of Natural Polyphenols by Chemiluminescence Technique. Proceedings of the 8th European Conference on Food Chemistry, European Chemical Society, Vienna, 18-20 September 1995, 639-643.

[52] Oluwatuyi, M., Kaatza, G.W. and Gibbons, S. (2004) Antibacterial and Resistance Modifying Activity of Rosmarinus officinalis. Phytochemistry, 65, 3249-3254. http://dx.doi.org/10.1016/j.phytochem.2004.10.009

[53] Aruoma, O.I., Spencer, J.P., Rossi, R., Aeschbach, R., Khan, A., Mahmood, N., Munoz, A., Murcia, A., Butler, J. and Halliwell, B. (1996) An Evaluation of the Antioxidant and Antiviral Action of Extracts of Rosemary and Provencal Herbs. Food and Chemical Toxicology, 34, 449-456. http://dx.doi.org/10.1016/0278-6915(96)00004-X

[54] Ramírez, P., García-Risco, M.R., Santoyo, S., Señoráns, F.J., Ibáñez, E. and Reglero, G. (2006) Isolation of Functional Ingredients from Rosemary by Preparative-Supercritical Fluid Chromatography (Prep-SFC). Journal of Pharmaceutical and Biomedical Analysis, 41, 1606-1613. http://dx.doi.org/10.1016/j.jpba.2006.02.001

[55] Altinier, G., Sosa, S., Aquino, R.P., Mencherini, T., Loggia, R.D. and Tubaro, A. (2007) Characterization of Topical Antiinflammatory Compounds in Rosmarinus officinalis L. Journal of Agricultural and Food Chemistry, 55, 17181723. http://dx.doi.org/10.1021/jf062610+

[56] Singletary, K., MacDonald, C. and Walling, M. (1996) Inhibition by Rosemary and Carnosol of 7,12-Dimethylbenz[a]Anthracene (DMBA)-Induced Rat Mammary Tumorigenesis and in Vivo DMBA-DNA Adduct Formation. Cancer Letters, 104, 43-48. http://dx.doi.org/10.1016/0304-3835(96)04227-9

[57] Okamura, N., Haraguchi, H., Hashimotok, K. and Yagi, A. (1994) Flavonoids in Rosmarinus officinalis Leaves. Phytochemistry, 37, 1463-1466. http://dx.doi.org/10.1016/S0031-9422(00)90434-5

[58] Cuvelier, M.E., Berset, C. and Richard, H. (1994) Antioxidant Constituents in Sage. Journal of Agricultural and Food Chemistry, 42, 665-669. http://dx.doi.org/10.1021/jf00039a012

[59] Aruoma, O.I., Halliwell, B., Aeschbach, R. and Loliger, J. (1992) Antioxidant and Pro-Oxidant Properties of Active Rosemary Constituents: Carnosol and Carnosic Acid. Xenobiotica, 22, 257-265. http://dx.doi.org/10.3109/00498259209046624

[60] Del Bano, M.J., Lorente, J., Castillo, J., Benavente-Garcia, O., Del Rio, J.A. and Ortuno, A. (2003) Phenolic Diterpenes, Flavones, and Rosmarinic Acid Distribution during the Development of Leaves, Flowers, Stems, and Roots of Rosmarinus officinalis. Journal of Agricultural and Food Chemistry, 51, 4247-4253. http://dx.doi.org/10.1021/jf0300745

[61] Haraguchi, H., Saito, T., Okamura, N. and Yagi, A. (1995) Inhibition of Lipid Peroxidation and Superoxide Generation by Diterpenoids from Rosmarinus offcinalis. Planta Medica, 61, 333-336. http://dx.doi.org/10.1055/s-2006-958094

[62] Zeng, H.H., Tu, P.F., Zhou, K., Wang, H., Wang, B.H. and Lu, J.F. (2001) Antioxidant Properties of Phenolic Diterpenes from Rosmarinus officinalis. Acta Pharmacologica Sinica, 22, 1094-1098.

[63] Escuder, B., Torres, R., Lissi, E., Labbé, C. and Faini, F. (2002) Antioxidant Capacity of Abietanes from Sphacele Salviae. Natural Product Letters, 16, 277-281. http://dx.doi.org/10.1080/10575630290020631

[64] Hra, H.R., Hadolina, M., Knez, E. and Bauman, D. (2000) Comparison of Antioxidative and Synergistic Effects of Rosemary Extract with $\alpha$-Tocopherol, Ascorbyl Palmitate and Citric Acid in Sunflower Oil. Food Chemistry, 71, 229233. http://dx.doi.org/10.1016/S0308-8146(00)00161-8

[65] Houlihan, C.M., Ho, C.T. and Chang, S.S. (1984) Elucidation of the Chemical Structure of a Novel Antioxidant, Rosmaridiphenol, Isolated from Rosemary. Journal of the American Oil Chemists' Society, 61, 1036-1039. http://dx.doi.org/10.1007/BF02636212 
[66] Houlihan, C.M., Ho, C.T. and Chang, S.S. (1985) The Structure of Rosmariquinone New Antioxidant isolated from Rosmarinus officinalis L. Journal of the American Oil Chemists' Society, 62, 96-98. http://dx.doi.org/10.1007/BF02541500

[67] Nakatani, N. and Inatani, R. (1984) Two Antioxidant Diterpenes from Rosemary (Rosmarinus officinalis L.) and a New Revised Structure for Rosmanol. Agricultural and Biological Chemistry, 48, 2081-2085. http://dx.doi.org/10.1271/bbb1961.48.2081

[68] Frankel, E.N., Huang, S.W., Aeschbach, R. and Prior, E. (1996) Antioxidant Activity of a Rosemary Extract and Its Constituents, Carnosic Acid, Carnosol, and Rosmarinic Acid, in Bulk Oil and Oil-in-Water Emulsion. Journal of Agricultural and Food Chemistry, 44, 131-135. http://dx.doi.org/10.1021/jf950374p

[69] Frankel, E.N., Huang, S.W., Prior, E. and Aeschbach, R. (1996) Evaluation of Antioxidant Activity of Rosemary Extracts, Carnosol, and Carnosic Acid in Bulk Vegetable Oils and Fish Oils and Their Emulsions. Journal of Agricultural and Food Chemistry, 72, 201-208. http://dx.doi.org/10.1002/(SICI)1097-0010(199610)72:2<201::AID-JSFA632>3.0.CO;2-Q

[70] Madsen, H.L., Andersen, L., Christiansen, L., Brockhoff, P. and Bertelsen, G. (1996) Antioxidative Activity of Summer Savory (Satureja hortensis L.) and Rosemary (Rosemarinus officinalis L.) in Minced, Cooked Pork Meat. Zeitschrift für Lebensmittel-Untersuchung und Forschung, 203, 333-338. http://dx.doi.org/10.1007/BF01231071

[71] Martinez-Tome, M., Jimenez, A.M. and Ruggieri, S. (2001) Antioxidant Properties of Mediterranean Spices Compared with Common Food Additives. Journal of Food Protection, 64, 1412-1419.

[72] Guo, Q., Zhao, B., Li, M., Shen, S. and Xin, W. (1996) Studies on Protecting Mechanisms of Four Components of Green Tea Polyphenols against Lipid Peroxidation in Synaptosomes. Biochimica et Biophysica Acta (BBA)—Lipids and Lipid Metabolism, 1304, 210-222. http://dx.doi.org/10.1016/S0005-2760(96)00122-1

[73] Basaga, H., Tekkaya, C. and Acikel, F. (1997) Antioxidative and Free Radical Scavenging Properties of Rosemary Extract. LWT-Food Science and Technology, 30, 105-108. http://dx.doi.org/10.1006/fstl.1996.0127

[74] Gad, A.S. and Abd El-Salam, M.H. (2010) The Antioxidant Properties of Skim Milk Supplemented with Rosemary and Green Tea Extracts in Response to Pasteurisation, Homogenisation and the Addition of Salts. International Journal of Dairy Technology, 63, 349-355. http://dx.doi.org/10.1111/j.1471-0307.2010.00585.x

[75] El-Din, H.M.F., Ghita, I.E., Badran, S.M.A., Gad, A.S. and El-Said, M.W. (2010) Manufacture of Low Fat UF-Soft Cheese Supplemented with Rosemary Extract (as Natural Antioxidant). Journal of American Science, 6, 570-579.

[76] Gad, A.S., Ghita, I.E., El-Din, H.M.F., Badran, S.M.A. and El-Messery, T.M. (2010) Production Health Benefits Yoghurt Supplemented with Rosemary and Green Tea Extract as Natural antioxidant. IDF World Dairy Summit, Auckland, 5-11.

[77] Al Zahal, O., Or-Rashid, M.M., Greenwood, S.L., Douglas, M.S. and McBride, B.W. (2009) The Effect of Dietary Fiber Level on Milk Fat Concentration and Fatty Acid Profile of Cows Fed Diets Containing Low Levels of Polyunsaturated Fatty Acid. Journal of Dairy Science, 92, 1108-1116. http://dx.doi.org/10.3168/jds.2008-1472

[78] Van Nieuwenhove, C.P., Oliszeski, R. and Gonzalez, S.N. (2009) Fatty Acid Composition and Conjugated Linoleic Acid Content of Cow and Goat Cheeses from Northwest Argentina. Journal of Food Quality, 32, 303-314. http://dx.doi.org/10.1111/j.1745-4557.2009.00258.x

[79] Kilcawley, K.N., O’Connell, P.B., Hickey, D.K., Sheehan, E.M., Beresford, T.P. and McSweeney, P.L.H. (2007) Influence of Composition on the Biochemical and Sensory Characteristics of Commercial Cheddar Cheese of Variable Quality and Fat Content. International Journal of Dairy Technology, 60, 81-88. http://dx.doi.org/10.1111/j.1471-0307.2007.00299.x

[80] Deeth, H.C. (2006) Lipoprotein Lipase and Lipolysis in Milk. International Dairy Journal, 16, 555-562. http://dx.doi.org/10.1016/j.idairyj.2005.08.011

[81] Fernandez-López, J., Zhi, N., Aleson-Carbonell, L., Alérez-Alvarez, J.A. and Kuri, V. (2005) Antioxidant and Bacterial Activities of Natural Extracts: Application in Beef Meatballs. Journal of Meat Science, 69, 371-380. http://dx.doi.org/10.1016/j.meatsci.2004.08.004

[82] Haliwell, B. and Gutteridge, J.M. (1992) Free Radicals, Antioxidants, and Human Disease-Where Are We Now. Journal of Laboratory and Clinical Medicine, 119, 598-620.

[83] Stevenson, D.E. and Hurst, R.D. (2007) Polyphenolic Phytochemicals—Just Antioxidants or Much More? A Review. Cellular and Molecular Life Sciences, 64, 2900-2916. http://dx.doi.org/10.1007/s00018-007-7237-1

[84] Coussens, L.M. and Werb, Z. (2002) Inflammation and Cancer. Nature, 420, 860-867. http://dx.doi.org/10.1038/nature01322

[85] Mueller, M.M. (2006) Inflammation in Epithelial Skin Tumours: Old Stories and New Ideas. European Journal of Cancer, 42, 735-744. http://dx.doi.org/10.1016/j.ejca.2006.01.014 
[86] Takaki, I., Bersani-Amado, L.E., Vendruscolo, A., Sartoretto, S.M., Diniz, S.P., Bersani-Amado, C.A. and Cuman, R.K.N. (2008) Anti-Inflammatory and Antinociceptive Effects of Rosmarinus officinalis L. Essential Oil in Experimental Animal Models. Journal of Medicinal Food, 11, 741-746. http://dx.doi.org/10.1089/jmf.2007.0524

[87] Pérez-Fons, L., Garzón, M.T. and Micol, V. (2010) Relationship between the Antioxidant Capacity and Effect of Rosemary (Rosmarinus officinalis L.) Polyphenols on Membrane Phospholipid Order. Journal of Agricultural and Food Chemistry, 58, 161-171. http://dx.doi.org/10.1021/jf9026487

[88] Inoue, K., Takano, H., Shiga, A., Fujita, Y., Makino, H., Yanagisawa, R., Ichinose, T., Kato, Y., Yamada, T. and Yoshikawa, T. (2005) Effects of Volatile Constituents of a Rosemary Extract on Allergic Airway Inflammation Related to House Dust Mite Allergen in Mice. International Journal of Molecular Medicine, 16, 315-319. 
Scientific Research Publishing (SCIRP) is one of the largest Open Access journal publishers. It is currently publishing more than 200 open access, online, peer-reviewed journals covering a wide range of academic disciplines. SCIRP serves the worldwide academic communities and contributes to the progress and application of science with its publication.

Other selected journals from SCIRP are listed as below. Submit your manuscript to us via either submit@scirp.org or Online Submission Portal.
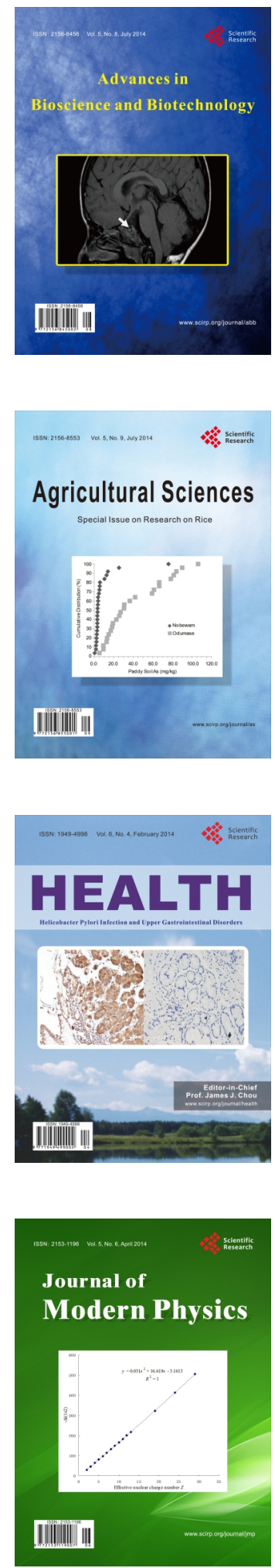
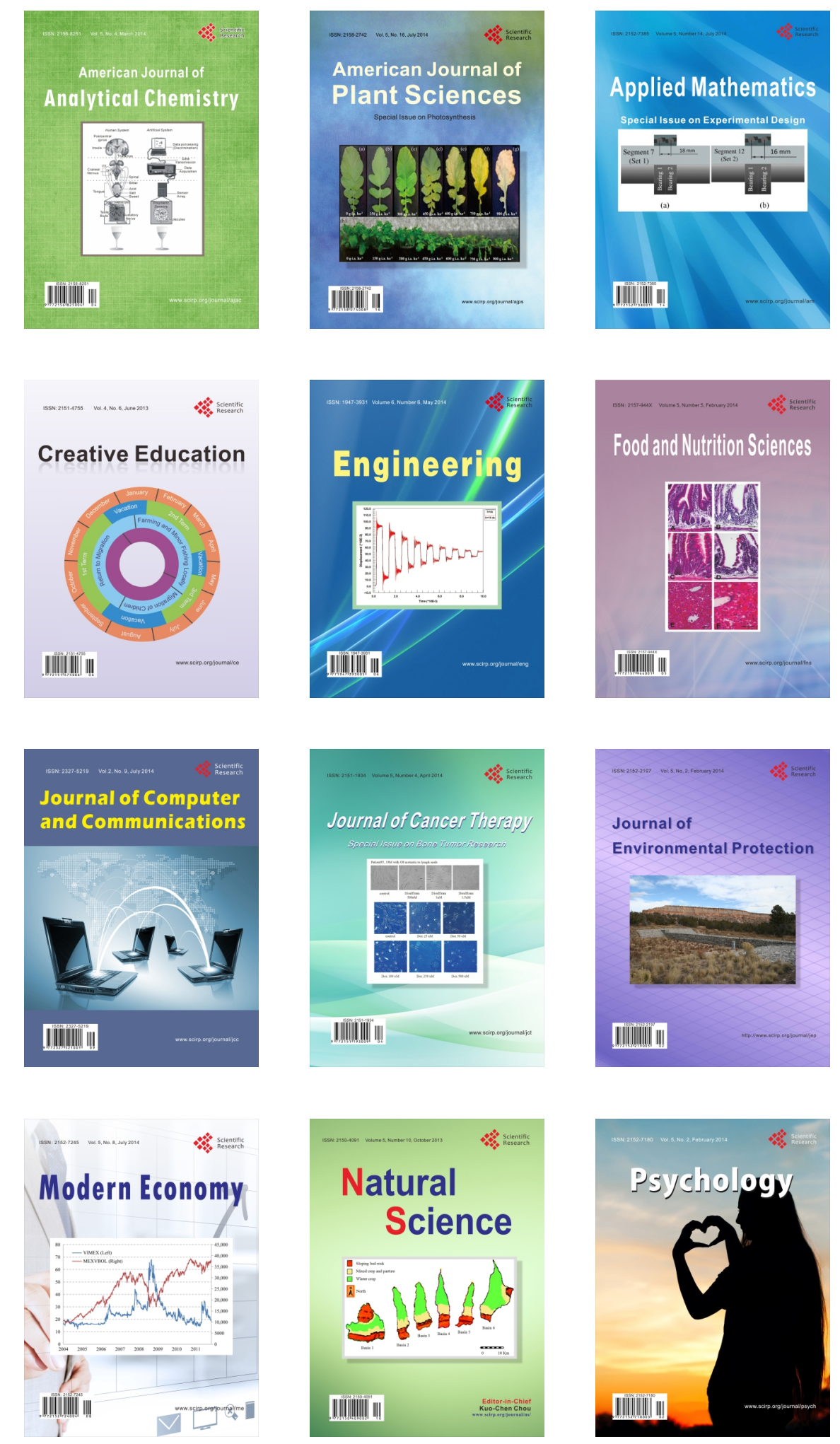